\title{
Racism in The $21^{\text {st }}$ Century: Debbie Tucker Green's Eye for Ear
}

\author{
Belgin Bağırlar \\ Aydın Adnan Menderes University, Education Faculty, Turkey
}

\begin{abstract}
Does equality exist in the 21st century, or, are minorities still forced to fight for equality? In 19th century Britain, racism was blatant in all spheres of cultural, social, and economic life to the point that it crossed over into literature and theatre. In 1978, UNESCO adopted the Universal Declaration of Human Rights. Forty years have since passed, but has it made any difference? Contemporary British playwright debbie tucker green's Eye for Ear (2018), staged at the Royal Court Theatre, reminds us that racism and inequality is still a key social-political issue. This three-act, avant-garde, colloquial play depicts how both African-Americans as well as Black British people still live with racism today. It also highlights racism's linguistic and legal past. Green particularly focuses on the violent aspect of that racism through the lens of different characters: an academic, a black student, a black boy, and black parents. The play concludes with crushed hope, for it deduces that Caucasians both in the United States and in Great Britain still dominate practically every facet of society. This study will examine Green's Ear for Eye, racial discrimination in the $21^{\text {st }}$ century, and how Tucker projects her views upon her work through the theory of race and racism.
\end{abstract}

Keywords: Contemporary theatre, Stuart Hall, violence, racism 